\title{
Effect of light-activation methods and water storage on the flexural strength of two composite resins and a compomer
}

\section{Efeito da fotoativação e da armazenagem em água na resistência à flexão de duas resinas compostas e um compômero}

\author{
Leonardo Eloy Rodrigues Filho* \\ Luis Antônio dos Santos Burger** \\ Silvia Kenshima*** \\ José Roberto de Oliveira Bauer**** \\ Igor Studart Medeiros* \\ Antonio Muench*****
}

\begin{abstract}
The present study evaluated the flexural strength of three composite resins recommended for direct esthetic restorations: a polyacid modified composite (Dyract AP), a unimodal composite resin (Filtek Z250) and a hybrid composite resin (Point 4). The variation factors, apart from the type of composite resin, were the light activation method and the water storage period. The composite resins were light-cured in continuous mode $(40 \mathrm{~s}$, $\left.500 \mathrm{~mW} / \mathrm{cm}^{2}\right)$ or in ramp mode $\left(0-800 \mathrm{~mW} / \mathrm{cm}^{2}\right.$ for $10 \mathrm{~s}$ followed by $30 \mathrm{~s}$ at $\left.800 \mathrm{~mW} / \mathrm{cm}^{2}\right)$ and stored for 24 hours or 30 days in distilled water at $37^{\circ} \mathrm{C}$. The data were analyzed by ANOVA and Tukey test for multiple comparisons $(\alpha=0.05)$. The composite resin $Z 250$ presented the highest mean flexural strength $(166.74 \mathrm{MPa})$ and Dyract AP presented the lowest one (129.76 $\mathrm{MPa})$. The storage for 30 days decreased the flexural strength in ramp mode (24 h: $156.64 \mathrm{MPa}$; 30 days: $135.58 \mathrm{MPa}$ ). The light activation method alone did not lead to different flexural strength values.
\end{abstract}

DESCRIPTORS: Compomers; Dental materials; Composite resins.

RESUMO: O presente estudo analisou a resistência à flexão de três compósitos recomendados para restaurações estéticas diretas: um compósito poliácido-modificado (Dyract AP), uma resina composta unimodal (Filtek Z250) e uma resina composta híbrida (Point 4). Os fatores de variação, além do tipo de compósito, foram o método de fotoativação e o periodo de armazenagem em água. Os materiais foram fotoativados continuamente por $40 \mathrm{~s}(500 \mathrm{~mW} /$ $\left.\mathrm{cm}^{2}\right)$ ou com intensidade de luz crescente $\left(0-800 \mathrm{~mW} / \mathrm{cm}^{2}\right.$ por $10 \mathrm{~s}$ seguidos de $30 \mathrm{~s}$ a $\left.800 \mathrm{~mW} / \mathrm{cm}^{2}\right)$. Os períodos de armazenagem foram de 24 horas ou 30 dias em água destilada a $37^{\circ} \mathrm{C}$. Os dados foram submetidos à análise de variância e ao teste de Tukey para comparações múltiplas $(\alpha=0,05)$. A resina composta Z250 apresentou a maior média de resistência à flexão $(166,74 \mathrm{MPa})$ e a Dyract AP, a menor $(129,76 \mathrm{MPa})$. A armazenagem por 30 dias diminuiu a resistência à flexão para o método de fotoativação crescente (24 h: 156,64 MPa; 30 dias: 135,58 MPa). O método de fotoativação isoladamente não conduziu a diferentes valores de resistência à flexão.

DESCRITORES: Compômeros; Materiais dentários; Resinas compostas.

\section{INTRODUCTION}

Light-cured composite resins have become an almost universal material in current dental practice. Although many studies concerning earlier generations of composite resins still emphasize their lower mechanical properties, the most recent composites have achieved wear resistance similar to that of amalgam restorations at the critical occlusal contact area ${ }^{11,17}$.
A variety of light activation methods and different sources were proposed aiming to improve the quality of the cure, which would assure the physical properties of the resulting composite resin restorations $\mathbf{s}^{4,15,25}$. Additionally, a slower polymerization rate could optimize the stress relief by flow at the early stages of the reaction ${ }^{7}$ and contribute to minimize the adverse effects related to polym-

\footnotetext{
* PhDs, Professors; ***MSc, PhD Student; *****Full Professor - Department of Dental Materials, School of Dentistry, University of São Paulo.

** MSc, Assistant Professor, Planalto Central Educational Union.

*** PhD, Private Practice, São Paulo, SP, Brazil.
} 
Rodrigues Filho LE, Burger LAS, Kenshima S, Bauer JRO, Medeiros IS, Muench A. Effect of light-activation methods and water storage on the flexural strength of two composite resins and a compomer. Braz Oral Res 2006;20(2):143-7.

erization shrinkage stress.

Recent studies have demonstrated that the light intensity does not significantly affect the polymerization shrinkage stress or the hardness of more superficial composite resin layers. However, significant differences were found in flexural strength when three different composite restorative materials were evaluated ${ }^{14,24}$.

The stability of the polymeric matrix and the formation of its degradation products are related to the effectiveness of the polymerization and the respective degree of cure. The dental composite resin has been demonstrated to be susceptible to many types of chemical degradation ${ }^{16,23}$.

There is evidence that the chemical degradation of composite resins occurs mainly by the diffusion of molecules and ions of non-reacted resin monomers. When composite resins are immersed in aqueous solutions, water absorption occurs between the polymer chains, promoting a swelling. This swelling may lead to decreased bond strength between the polymer chains. Moreover, the ceramic particle/resinous matrix interface can be attacked at the silane agent lowering the composite's mechanical properties ${ }^{2,23}$.

Compomers set through a free radical polymerization reaction activated by light, and it has been speculated that a late acid-base reaction would occur with water sorption. For this purpose, part of the filler in their composition (ion-leachable glass) is not silanized and could be attacked by the acidic components of the resinous matrix ${ }^{22}$.

Considering resin-based materials, it was observed that there is a close relation between the water sorption of the cured composite and water uptake of their monomers ${ }^{1}$. Therefore, it seems reasonable to suppose that the mechanism of water sorption can be also influenced by the light activation method considering possible differences in the polymer network and residual monomers.

The objective of this study was to evaluate the influence of two light activation methods with different energy densities and different water storage periods on the flexural strength of two composite resins and one compomer.

\section{MATERIALS AND METHODS}

The materials applied in this study were the composite resins Filtek Z250 (3M ESPE, St. Paul, MN, USA), Point 4 (SDS/Kerr, Orange, CA, USA), and the compomer Dyract AP (Dentsply/Caulk, Milford, DE, USA), shade A3.5 (Vita shade guide - Vita Zahnfabrik, Säckingen, Germany). Their compositions are discriminated in Table 1.

The test was performed according to ISO $4049^{12}$, and bar shaped specimens of reduced dimensions ( $1 \times 2 \times 10 \mathrm{~mm})$ were adopted, as suggested in previous work ${ }^{5}$. They were prepared with a stainless steel mold in which the composite resin was inserted and sandwiched between mylar strips and glass slides pressed by a load of $8 \mathrm{kgf}$ to standardize their thickness.

They were light-cured in continuous mode $\left(500 \mathrm{~mW} / \mathrm{cm}^{2}\right.$ for $\left.40 \mathrm{~s}-20.000 \mathrm{~mJ} / \mathrm{cm}^{2}\right)$ with Optilux 500 (SDS/Kerr, Orange, CA, USA) or in ramp mode (for $10 \mathrm{~s}$ from 0 to $800 \mathrm{~mW} / \mathrm{cm}^{2}$ with an average $80 \mathrm{~mW} / \mathrm{cm}^{2}+30 \mathrm{~s}$ with $800 \mathrm{~mW} / \mathrm{cm}^{2}-800+$ $\left.24.000=24.800 \mathrm{~mJ} / \mathrm{cm}^{2}\right)$ with Optilux 501 (SDS/ Kerr, Orange, CA, USA).

The specimens were stored in opaque flasks with distilled water at $37^{\circ} \mathrm{C}$, for 24 hours or 30 days. Five replicates $(n=5)$ were made for each of the 12 experimental conditions ( 3 composite resins versus 2 light activation methods versus 2 storage periods), totalling 60 specimens.

The three-point bending test was performed in a universal testing machine (Kratos Dinamômetros, São Paulo, Brazil). The specimens were placed on the testing device with their larger surface facing the two parallel cylinder spans $(2 \mathrm{~mm}$ diameter) that were $8 \mathrm{~mm}$ apart. The load was applied at mid-span through a wedge-shaped probe with a bar of $2 \mathrm{~mm}$ in diameter at a crosshead speed of $0.5 \mathrm{~mm} / \mathrm{min}$. The maximum load applied

TABLE 1 - Composition of the composite resins*.

\begin{tabular}{|c|c|c|c|c|c|}
\hline $\begin{array}{l}\text { Product } \\
\text { (Manufacturer) }\end{array}$ & Filler composition & Filler size $(\mu \mathrm{m})$ & $\begin{array}{l}\text { \% Filler } \\
\text { (volume) }\end{array}$ & Monomer (matrix) & $\begin{array}{c}\text { Batch } \\
\text { number }\end{array}$ \\
\hline Filtek Z250 (3M) & $\mathrm{Zr} / \mathrm{Si}$ & $0.6(0.01-3.5)$ & 60 & Bis-GMA, UDMA, Bis-EMA & 1370 \\
\hline Dyract AP (Dentsply) & Sr-Al-F-P-Si & 0.8 & 47 & UDMA, TCB & 01067 \\
\hline Point 4 (Kerr) & $\mathrm{Ba}-\mathrm{Al}-\mathrm{Si}, \mathrm{ZnO}$ & 0.4 & 57 & Bis-GMA, TEGDMA & 005656 \\
\hline
\end{tabular}

*According to information provided by the manufacturers. 
Rodrigues Filho LE, Burger LAS, Kenshima S, Bauer JRO, Medeiros IS, Muench A. Effect of light-activation methods and water storage on the flexural strength of two composite resins and a compomer. Braz Oral Res 2006;20(2):143-7.

TABLE 2 - Flexural strength means for the storage versus composite resin interaction and main factors (MPa).

\begin{tabular}{l|c|c|c}
\hline \hline \multirow{2}{*}{ Storage } & \multicolumn{3}{|c}{ Composite resin } \\
\cline { 2 - 4 } & Z250 & Dyract AP & Point 4 \\
\hline 24 hours & $171.79^{\mathrm{a}}$ & $145.01^{\mathrm{b}}$ & $149.25^{\mathrm{b}}$ \\
\hline 30 days & $161.70^{\mathrm{a}}$ & $114.52^{\mathrm{c}}$ & $146.72^{\mathrm{b}}$ \\
\hline \hline
\end{tabular}

Different symbols indicate statistically significant difference $(\mathrm{p}<0.05)$.

before failure was used to calculate the flexural strength $(\sigma, \text { Eq. } 1)^{12}$ :

$$
\sigma=\frac{3 \mathrm{Fl}}{2 \mathrm{bh} \mathrm{h}^{2}}(1)
$$

In Equation 1, $\mathrm{F}$ is the applied load $(\mathrm{N})$ at the highest point of the load-deflection curve, 1 is the distance between the spans $(\mathrm{mm}), \mathrm{b}$ is the width $(\mathrm{mm})$ and $\mathrm{h}$ is the height $(\mathrm{mm})$ of the barshaped specimen that was individually measured with a $0.01 \mathrm{~mm}$ precision digital caliper (Absolute Digimatic, Mitutoyo, Tokyo, Japan). The flexural strength values $(\mathrm{MPa})$ were analyzed by 3-way ANOVA and Tukey test at the 0.05 level of significance (Minitab 13.1 - Minitab Ltd., Pennsylvania, USA).

\section{RESULTS}

The 3-way ANOVA showed that the main factors composite resin $(Z 250=166.74 \mathrm{MPa}$; Dyract $\mathrm{AP}=129.76 \mathrm{MPa}$; Point $4=147.99 \mathrm{MPa}$ ) and storage $(24 \mathrm{~h}=155.35 \mathrm{MPa} ; 30$ days $=140.98 \mathrm{MPa})$ were statistically significant, but the main factor light activation was not. Considering the interactions, only storage versus composite resin and storage $\mathrm{x}$ light activation were significant (respectively $\mathrm{p}=0.000$ and $\mathrm{p}=0.005$ ). This fact will lead to the present results and discussion connected to the corresponding mean values (Tables 2 and 3).

The mean values in the Table 2 were calculated considering the means of both light activation methods. For example: $24 \mathrm{~h}$ versus $\mathrm{Z} 250$ $(171.79 \mathrm{MPa})=[24 \mathrm{~h}$ versus $\mathrm{Z} 250$ versus continuous $(173.41 \mathrm{MPa})+24 \mathrm{~h}$ versus $\mathrm{Z} 250$ versus ramp $(170.16 \mathrm{MPa})] / 2$. The storage time did not decrease significantly the flexural strength values of the composite resins (Z250 and Point 4). On the other hand, Dyract AP presented significantly lower

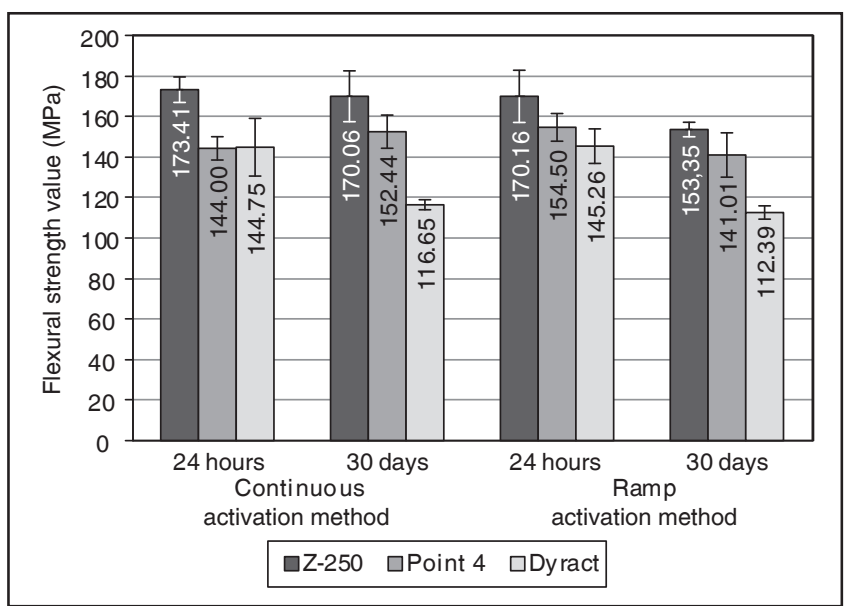

GRAPH 1 - Flexural strength mean values (MPa) and standard deviation bars for all the 12 experimental groups.

TABLE 3 - Flexural strength means for the storage versus light activation method interaction (MPa).

\begin{tabular}{l|c|c}
\hline \hline \multirow{2}{*}{$\begin{array}{l}\text { Light activation } \\
\text { method }\end{array}$} & \multicolumn{2}{|c}{ Storage } \\
\cline { 2 - 3 } & 24 hours & 30 days \\
\hline Ramp & $156.64^{\mathrm{a}}$ & $135.58^{\mathrm{c}}$ \\
\hline Continuous & $154.05^{\mathrm{a}, \mathrm{b}}$ & $146.38^{\mathrm{b}}$ \\
\hline \hline
\end{tabular}

Different symbols indicate statistically significant difference $(\mathrm{p}<0.05)$.

flexural strengths after 30 days of water storage. Table 2 also shows that material Z250 presented significantly superior flexural strength values than Point 4, and Dyract AP.

The results in Table 3 were calculated similarly considering the means of the three materials for each of the storage versus light activation method combinations. The light activation method had no influence after the $24 \mathrm{~h}$ storage. But after the 30 days storage, the ramp method presented significantly decreased flexural strength values. Graph 1 shows that with the continuous method only the material Dyract suffered a numerically high flexural strength value drop, but with the ramp method the other two materials also presented a numerically flexural strength value decrease.

Graph 1, correspondent to the interaction storage versus material versus light activation or to the 12 experimental conditions, shows that the flexural strength values of the compomer decreased after 30 days of water storage with both activation methods as shown in Table 2. 
Rodrigues Filho LE, Burger LAS, Kenshima S, Bauer JRO, Medeiros IS, Muench A. Effect of light-activation methods and water storage on the flexural strength of two composite resins and a compomer. Braz Oral Res 2006;20(2):143-7.

\section{DISCUSSION}

In this study, the comparison between the light activation methods was made solely by the mechanical parameter of flexural strength. The three-point bending test was adopted to evaluate the composite resins' mechanical properties. The flexural strength test is essentially a tensile strength test in which a static load is applied to the specimen. The resulting deformation provokes shortening of the specimen's surface and stretching of the base, which corresponds, respectively, to a compressive and tensile stress distribution inside the bending specimen. From this perspective, a continuous or ramp mode is indifferent, and both achieved high flexural strength values.

In a way, these results could be expected, considering that the light curing units could be classified as high-intensity when compared to the older ones. Besides, a relatively long exposure time was applied and the materials used in this study were only $1 \mathrm{~mm}$ thick. It was previously reported by Unterbrink, Muessner ${ }^{26}$ (1995) that the composite resin's mechanical properties depend on light intensity, but a $40 \mathrm{~s}$ exposure of 250 or $450 \mathrm{~mW} / \mathrm{cm}^{2}$ produced similar Vickers hardness until depths of $4.5 \mathrm{~mm}^{26}$. Similarly, Miyazaki et al. ${ }^{19}$ (1996) reported no flexural strength difference among composite resins cured with different light intensities and exposure times. It is possible that the polymerization degree is more directly related to the photoinitiators than to light activation method ${ }^{10}$.

The interaction storage versus composite resin was significant. It is notable that this result occurred mainly because of the storage different effect on Dyract AP, that presented a flexural strength decrease after 30 days of water storage independently of the light activation method. These results are in agreement with those found by many authors like Irie, Nakai ${ }^{13}$ (1998) that reported flexural strength reduction in compomers after one week of water storage. A microhardness reduction was also observed for compomers stored in artificial saliva ${ }^{9}$. A 20 to $80 \%$ reduction in flexural strength was also found in resin modified glass ionomers after water storage ${ }^{3}$.

Contrarily to the results of the present study, Yap et al. ${ }^{27}$ (2002) reported a rise in flexural strength of polyacid modified composite resins with increased water storage periods. This finding was attributed to a significant increase of the late polymerization reaction of this class of material. These results were supported by another study in which Fourier-transform infrared (FT-IR) spectroscopy recorded changes in compomers following storage in the aqueous media in the region of the spectra associated with metal carboxylates, indicating that a secondary acid-base reaction had occurred following water uptake ${ }^{20}$.

It is likely that an important continuous polymerization reaction might occur and be materialdependant. Although all the tested materials can be classified as composite resins, their compositions are very different, both in the organic and in the inorganic content. It is known that different compositions usually lead to distinct mechanical strength $^{21}$. Therefore, within the experimental conditions adopted in this study, the factors related to water degradation might have influenced the flexural strength resulting in lower values after the longer storage period.

The fact that Dyract AP achieved the lowest flexural strength value is also well documented in the literature ${ }^{6}$. Compomers were previously regarded as polyacid modified composite resins with inferior mechanical properties compared to composite resins ${ }^{18}$. The highest flexural strength mean achieved by Z250 (166.74 MPa) can be attributed to a conjunction of factors related to its composition. Among these factors is the shape of its inorganic particles that allows high volumetric filler content ${ }^{8}$. Higher strength values were also reported for a similar composite resin, $Z-100^{6}$.

In a previous study, a hypothesis was supported that a high-intensity light might cause failure in polymer chain growth and cross-linking, affecting its structure and properties, among other mechanical properties tested, solely by a decrease in hardness when the plasma-arc light was used ${ }^{24}$. No such effect was observable for the conventional quartz-tungsten-halogen (QTH) light and a softstart light. However, as only the immediate results were evaluated, it is possible that the effect of the light curing method remained undetected for the other mechanical properties assessed.

In the present study, the interaction light activation method versus storage was also significant and lower flexural strength values were observed for the ramp mode after 30 days stored in water. This suggests that the light activation method might be related to water sorption mechanisms, as this difference was not observed for the continuous mode.

However, more specific studies would be necessary to properly address this matter since, in this study, the lowest values were observed for Dyract 
Rodrigues Filho LE, Burger LAS, Kenshima S, Bauer JRO, Medeiros IS, Muench A. Effect of light-activation methods and water storage on the flexural strength of two composite resins and a compomer. Braz Oral Res 2006;20(2):143-7.

AP, which was also the most susceptible of the composite resins to the water storage regarding flexural strength. It is important to consider that compomers were reported to present lower biaxial flexure strength than composite resins when exposed to different acidic storage solutions ${ }^{20}$. Therefore, further investigation is necessary to clarify the sorption effect in water degradation of composite resins. It should include other factors such as polymerization degree, controlled fluid transit and mass gain after different storage periods and aqueous medium.

\section{REFERENCES}

1. Atai M, Nekoomanesh M, Hashemi SA, Amani S. Physical and mechanical properties of an experimental dental composite based on a new monomer. Dent Mater 2004;20(7):663-8.

2. Calais JG, Soderholm KJ. Influence of filler type and water exposure on flexural strength of experimental composite resins. J Dent Res 1988;67(5):836-40.

3. Cattani-Lorente MA, Dupuis V, Payan J, Moya F, Meyer JM. Effect of water on the physical properties of resin-modified glass ionomer cements. Dent Mater 1999;15(1):71-8.

4. Cobb DS, Vargas MA, Rundle T. Physical properties of composites cured with conventional light or argon laser. Am J Dent 1996;9(5):199-202.

5. Correa IC, Muench A, Ballester RY. Flexural strength of composite related of specimens dimensions and photoactivation [abstract]. J Dent Res 2001;80(4):1002.

6. el-Kalla IH, Garcia-Godoy F. Mechanical properties of compomer restorative materials. Oper Dent 1999;24(1):2-8.

7. Feilzer AJ, de Gee AJ, Davidson CL. Setting stresses in composites for two different curing modes. Dent Mater 1993;9(1):2-5.

8. Filtek Z250 [description]. Reality 2000;14:309 (hybrids).

9. Geurtsen W, Leyhausen G, Garcia-Godoy F. Effect of storage media on the fluoride release and surface microhardness of four polyacid-modified composite resins ("compomers"). Dent Mater 1999;15(3):196-201.

10. Hofmann N, Hugo B, Schubert K, Klaiber B. Comparison between a plasma arc light source and conventional halogen curing units regarding flexural strength, modulus, and hardness of photoactivated resin composites. Clin Oral Investig 2000;4(3):140-7.

11. Hu X, Marquis PM, Shortall AC. Two-body in vitro wear study of some current dental composites and amalgams. J Prosthet Dent 1999;82(2):214-20.

12. International Standard Organization. ISO4049 - Dentistry: resin-based filling materials. Technical corrigendum, 1. Switzerland: ISO; 1988.

13. Irie $M$, Nakai $H$. Flexural properties and swelling after storage in water of polyacid-modified composite resin (compomer). Dent Mater J 1998;17(1):77-82.

14. Kleverlaan CJ, de Gee AJ. Curing efficiency and heat generation of various resin composites cured with high-intensity halogen lights. Eur J Oral Sci 2004;112(1):84-8.

15. Koran P, Kurschner R. Effect of sequential versus continuous irradiation of a light-cured resin composite on

\section{CONCLUSIONS}

1. Different flexural strength values were observed for the tested composite resins. Z250 presented the highest ones.

2. The longer water storage period produced lower flexural strength values for Dyract AP.

\section{ACKNOWLEDGEMENTS}

The authors would like to thank NAPEM and Antônio Carlos Lascala for technical support.

shrinkage, viscosity, adhesion, and degree of polymerization. Am J Dent 1998;11(1):17-22.

16. Lee SY, Huang HM, Lin CY, Shih YH. Leached components from dental composites in oral simulating fluids and the resultant composite strengths. J Oral Rehabil 1998;25(8):575-88.

17. Lutz F, Krejci I. Amalgam substitutes: a critical analysis. J Esthet Dent 2000;12(3):146-59.

18. Meyer JM, Cattani-Lorente MA, Dupuis V. Compomers: between glass-ionomer cements and composites. Biomaterials 1998;19(6):529-39.

19. Miyazaki M, Oshida Y, Moore BK, Onose H. Effect of light exposure on fracture toughness and flexural strength of light-cured composites. Dent Mater 1996;12(6):32832.

20. Nicholson JW, Gjorgievska E, Bajraktarova B, McKenzie MA. Changes in properties of polyacid-modified composite resins (compomers) following storage in acidic solutions. J Oral Rehabil 2003;30(6):601-7.

21. Reinhardt JW, Boyer DB, Stephens NH. Effects of secondary curing on indirect posterior composite resins. Oper Dent 1994;19(6):217-20.

22. Ruse ND. What is a "compomer"? J Can Dent Assoc 1999;65(9):500-4.

23. Soderholm KJ. Degradation of glass filler in experimental composites. J Dent Res 1981;60(11):1867-75.

24. St-Georges AJ, Swift EJ, Thompson JY, Heymann HO. Irradiance effects on the mechanical properties of universal hybrid and flowable hybrid resin composites. Dent Mater 2003;19(5):406-13.

25. Stahl F, Ashworth SH, Jandt KD, Mills RW. Lightemitting diode (LED) polymerization of dental composites: flexural properties and polymerization potential. Biomaterials 2000;21(13):1379-85.

26. Unterbrink GL, Muessner R. Influence of light intensity on two restorative systems. J Dent 1995;23(3):183-9.

27. Yap AU, Chandra SP, Chung SM, Lim CT. Changes in flexural properties of composite restoratives after aging in water. Oper Dent 2002;27(5):468-74.

Received for publication on May 10, 2005

Sent for alterations on Nov 10, 2005

Accepted for publication on Apr 27, 2006 